\title{
Popkulturowe wojny na noże i widelce - deskrypcja współczesnego serbskiego i chorwackiego gastronacjonalizmu
}

\begin{abstract}
Knife and Fork Wars: a Description of Contemporary Serbian and Croatian Gastronationalism

The aim of the text is to demonstrate the unusual vitality of the nationalist discourse of today's Croatia and Serbia, which explicitly draws on the nationalism of the 1990s that marked the beginning of the new nation states established after the collapse of Yugoslavia. Despite the passage of time, the trite nationalism, i.e. the one visible in the pop-culture, remains a major element of the political life and a guarantor of the state which can be called after Danilo Kiš a state of deep nationalist paranoia. The reflection has been inspired by the current political events, concentrated around the seemingly innocent elements of the pop culture (cuisine), which constitute a telling litmus paper of both the transitions that took place in the face of intensification of the war-induced identity-related discourse, as part of which the various canons of national cultures were reinterpreted, and of the contemporary Serbian and Croatian acts of "pop-cultural knife and fork wars". The text constitutes an attempt to describe the post-Yugoslav "nationalist menu", it contains various cultural texts, the selection of which shows the complexity of the problem.
\end{abstract}

Keywords: gastronationalism, popular culture, cuisine, banal nationalism, Serbia, Croatia. 


\begin{abstract}
„Swoją książkę o titowskiej Jugosławii angielski korespondent rozpoczął od żartu, z którego podobno śmiali się wszyscy. Wkrótce po zakończeniu wojny pewien człowiek wzniósł okrzyk: «Precz ze Stalinem!», za co przesiedział długie lata w więzieniu. Kiedy odbył już karę, za nic w świecie nie chciał powtórzyć tego samego błędu, więc głośno wyraził swoje uczucia: «Niech żyje Stalin!», i natychmiast na cztery kolejne lata został pozbawiony wolności. My, urodzeni po drugiej wojnie światowej, poznaliśmy dalszą część tego żartu: ponieważ więzienny wikt był podły, nieszczęśnik marzył przez długi czas, by zjeść coś słodkiego. Gdy po raz drugi wyszedł $\mathrm{z}$ więzienia, niemal natychmiast udał się do cukierni, gdzie zamówił baklawę. Kelner zapytał go, czy życzy sobie grecką, czy turecką, wtedy ów człowiek przestraszył się i zrezygnował z ciastka. Na wszelki wypadek, żeby znów coś nie wyszło na opak"’.
\end{abstract}

Inspiracją do powstania niniejszego tekstu stały się wydarzenia z przełomu 2016 i 2017 roku, stanowiące dowód na to, że mimo upływu blisko ćwierćwiecza od wojny po rozpadzie Jugosławii współczesna Serbia i Chorwacja wciąż głęboko tkwią w nacjonalistycznym dyskursie lat 90. Jak w przytoczonej anegdocie, tak w dzisiejszej sytuacji politycznej, którą za Danilo Kišem nazwać by można stanem głębokiej paranoi ${ }^{2}$, ideologia wkracza we wszystkie zakamarki rzeczywistości, gdzie nawet wybór deseru staje się deklaracją polityczną.

(Pop)kulturowe wojny ${ }^{3}$, stanowiące przedmiot tego tekstu, także rozpętane zostały z powodu... ciasteczka. Najpierw w atmosferze międzynarodowego skandalu prezydent Chorwacji Kolinda Grabar-Kitarović wręczyła dzieciom w Dubrowniku słodycze, wśród których znalazły się łakocie wyprodukowane w Serbii. Następnie okazało się, że również z serbskiej fabryki pochodzi đuveč - potrawka warzywna, którą karmieni są żołnierze chorwackich sił zbrojnych. Z kolei łakocie ofiarowane z okazji katolickich świąt Bożego Narodzenia wyłącznie dzieciom chorwackiego pochodzenia podzieliły media, a także, i tak już podzieloną, dwuetniczną szkołę podstawową w Vukovarze. Pikanterii sprawie dodał ostatecznie premier $^{4}$ Serbii Aleksander Vučić, który w trakcie konferencji prasowej, zwołanej na wieść o zaminowaniu torów, po których przejechać miał do Kosowa serbski pociąg oklejony prawosławnymi ikonami i napisami „Kosowo jest serbskie”, odnalazł wspólny mianownik wszystkich tych wydarzeń:

${ }^{1}$ B. Jezernik, Naga wyspa. Gułag Tity, przeł. J. Pomorska i J. Sławińska, Wołowiec 2013, s. 11.

2 „Nacjonalizm, to przede wszystkim paranoja. Zbiorowa i indywidualna paranoja. Jako zbiorowa paranoja jest on konsekwencją zawiści i strachu, a nade wszystko konsekwencją utraty indywidualnej świadomości; z kolei zbiorowa paranoja to nic innego jak zbiór indywidualnych paranoi doprowadzony do paroksyzmu", D. Kiš, Esej o nacionalizmu [w:] Čas anatomije, Belgrad 1978, https://www.scribd. com/doc/81941520/Danilo-Ki\%C5\%A1-Esej-o-nacionalizmu (dostęp: 1.02.2017).

${ }^{3}$ Zob. W.J. Burszta, W. Kuligowski, Kotwice pewności. Wojny kulturowe z popnacjonalizmem w tle, Warszawa 2013.

${ }^{4}$ Obecnie także prezydent elekt, wybrany na stanowisko 2 kwietnia 2017 roku, funkcję głowy państwa Aleksandar Vučić ma objąć w czerwcu br. 
Serbia chce pokoju. Zwracam się do Serbów - pozostańcie spokojni, a moje ostatnie ostrzeżenie i prośba do Albańczyków na Kosowie i Metochii brzmi: nie próbujcie atakować Serbów zbrojnie, ponieważ Serbia na to nie pozwoli. Do tego, kto pomyślał o tym, aby zabijać Serbów, bo czuje, że ma siłę, kieruję ostatni raz prośbę, by nie przyszło mu nawet na myśl, aby to uczynić. Proszę ich tylko o to, żeby nie zabijali Serbów, nigdy więcej! Bowiem będziemy musieli chronić nasz naród. (...) Pokój jest całkowicie w interesie każdego, niech zatem oni nie urządzają sobie zabaw i nie niszczą tego, co tak długo budowaliśmy, czyli pokoju i bezpieczeństwa wszystkich obywateli. Pociąg ze zwykłymi podróżnymi nie jest żadną groźbą, podobnie zresztą jak groźbą nie są czekoladka czy đuvečs.

Niezapoznany ze współczesną sceną polityczną odbiorca mógłby mieć wrażenie, że wsiadł do wehikułu czasu i ot, wylądował na tej samej szerokości geograficznej, tyle że w wojennych latach 90 . Zapewne zadałby sobie także absurdalnie brzmiące pytanie: co łączy pociąg, słodycze i ryżowo-warzywną potrawkę?! Vučić jednak, wykorzystując wszystkie elementy zestawienia ,na zasadzie metonimii”, w klasycznym nacjonalistycznym modelu siania strachu, którego naczelne hasło brzmi: „wszyscy są przeciwko »nam« Serbom, dlatego też przeszkadza »im« wszystko, co serbskie »od czekoladki do lokomotywy «"", potrafi w tym absurdzie odnaleźć logikę̧. Szczególnie w obliczu trwającej wówczas w Serbii kampanii prezydenckiej ${ }^{9}$, zakończonej zresztą zdecydowanym zwycięstwem premiera. Jednak kompleksową odpowiedź, której poszukiwaniu poświęcone jest niniejsze studium, odnajdywać należy w charakteryzującym się niezwykle długim trwaniem nacjonalizmie, silnie zakorzenionym w postjugosłowiańskiej rzeczywistości politycznej od lat 90 .

\section{Nacjonalizm od kuchni}

Materiał interpretacyjny niniejszej analizy stanowią rozmaite teksty kultury, co poświadcza kompleksowość problemu. Postanowiłam przedstawić fragmenty tekstów publicystycznych, autorstwa takich publicystów jak Boris Dežulović czy Teofil Pančić, którzy od lat komentują wydarzenia społeczno-polityczne regionu (także w wojennej dekadzie XX wieku). Tematyczne z kolei granice wyznacza dyskurs nacjonalistyczny, przejawiający się w obrębie kulinariów, których pozorna banalność dodatkowo podkreśla wszechobecność nacjonalistycznej paranoi.

${ }^{5} \mathrm{http}$ //www.alo.rs/vucic-odlucio-sam-da-zaustavim-voz-u-raskoj/91062 (dostęp: 14.01.2017). Jeśli nie zaznaczono inaczej, wszystkie tłumaczenia pochodzą od autorki tekstu.

${ }^{6}$ D. Ilić, Čokoladice, đuveč $i$ voz, Peščanik 16.01.2017, http://pescanik.net/cokoladice-duvecvoz/ (dostęp: 16.01.2017).

7 Aluzja do chorwackiego powiedzenia „,Od igle do lokomotive”, dosł. od igły do lokomotywy, oznaczającego wszystko - szwarc, mydło i powidło, od A do Z. Zob. ibid.

${ }^{8}$ Podobnie jak udało mu się powiązać stosunki Serbii i Chorwacji z kontaktami Serbii i Kosowa, które wszak nie mają z sobą aż tyle wspólnego, biorąc pod uwagę, że w odróżnieniu od Kosowa Serbia mimo wszystko uznaje istnienie Chorwacji.

9 Którą radykalne ugrupowanie NSN [Serbska partia postępowa], na którego czele stoi, oparło na generowaniu poczucia strachu, przy równoczesnym prezentowaniu siebie jako jedynej obrony przed realną groźbą. Jak wskazał w przemówieniu Vučić, osobiście podjął decyzję o zatrzymaniu pociągu i „osobiście jest z tego dumny”, zob. D. Ilić, op. cit. 
Blisko związane ze sferą profanum kulinaria są przykładem tekstów stanowiących ważny wątek kultury popularnej oraz częsty przedmiot refleksji antropologicznej ${ }^{10}$. Badania dotyczące kulinariów koncentrują się zwykle na kwestiach rozróżnień klasowych i zagadnieniach pozycji społecznej ${ }^{11}$. W kontekście refleksji nad wspólnotami narodowymi, interesuje mnie jednak przede wszystkim ich związek z tożsamością. Wydaje się on nieunikniony, głównie ze względu na traktowanie kulinariów jako identyfikujących „fragmentów narodowej tradycji”"12, współtworzących kanony i zbiory ,inwentarzy oczywistych dla członków społeczności”13, które wyznaczają pola wspólnych znaczeń w kontakcie z innym i obcym. Analizowany typ nacjonalizmu to nie ten występujący w swojej ,,paskudnej złowrogiej formie"14, lecz powszechny, z zakresu kultury popularnej, który za Krzysztofem Jaskułowskim nazwać można „McNacjonalizmem” ${ }^{15}$. Chodzi o banalną ${ }^{16}$ wersję zjawiska, które w wyniku „macdonaldyzacji”, czyli przenikania do popkultury”", szczególnie zaznaczyło swoją obecność w życiu codziennym. Specyficzną jego formą jest gastronacjonalizm.

${ }^{10}$ Poczynając od klasycznego artykułu Levi-Straussa Trójkąt kulinarny, który miał przynosić niezbite dowody na to, że sposób przyrządzania jedzenia w każdej kulturze tworzą starannie wypracowane struktury. Badania dotyczące związku osadzonych w codzienności kulinariów i tożsamości zaznaczyły swoją obecność także później w ramach ustaleń takich badaczy, jak Tim Edensor, Michael Billig czy Eric Hobsbawm. W swojej Tożsamości narodowej, kulturze popularnej i życiu codziennym Edensor analizuje mity i ikony banalnego nacjonalizmu, posiłkując się przede wszystkim sformułowaną przez Billiga tezą o tożsamości narodowej tkwiącej w tym, co banalne i codzienne. Badając najróżniejsze przejawy codzienności, Edensor dochodzi do wniosku, iż moc potocznego nacjonalizmu kierowana jest przez działania polityczne i tkwi w codziennych popkulturowych mechanizmach. Chociaż w centrum zainteresowania Edensora znajduje się przede wszystkim typologia przestrzeni narodowej, dokonuje on również analizy rozmaitych inscenizacji tożsamości narodowej. Podkreśla, że poszczególne narody cały czas biorą udział w inscenizowaniu swojej tożsamości narodowej. Nawiązując do Hobsbawma i jego Tradycji wynalezionej, podkreśla, że źródeł inscenizacji czy też nawyków nie muszą wcale oznaczać historyczne tradycje czy zdroworozsądkowe mechanizmy. Badania te dowodzą, jak głęboko nacjonalizm wdarł się w tkankę niewinnych, codziennych czynności, sprawiając, że nawet takie dziedziny codzienności jak badana przez Edensora motoryzacja, muzyka opisywana przez Hobsbawma czy prognoza pogody, będąca przedmiotem analizy Billiga, mogą stać się sceną inscenizacji tożsamościowych. Zob. T. Edensor, Tożsamość narodowa, kultura popularna i życie codzienne, przeł. A. Sadza, Warszawa 2004; E. Hobsbawm, Tradycja wynaleziona, przeł. M. Godyń i F. Godyń, Kraków 2008; M. Billig, Banalni nacjonalizam, przeł. V. Kostić, Biblioteka XX wieku, Beograd 2005.

${ }^{11}$ F. Fernàndez-Armesto, Wokól tysiaca stołów czyli o historii jedzenia, przeł. J. Jackowicz, Warszawa 2003, s. 243-244; P. Bourdieu, Dystynkcja. Społeczna krytyka władzy sądzenia, przeł. P. Biłos, Warszawa 2005; M. de Certeau, Wynaleźć codzienność. Sztuki działania, przeł. K. Thiel-Jańczuk, Warszawa 2004.

${ }^{12}$ K. Łeńska-Bąk, Kulinaria i dyskurs tożsamości [w:] Polacy o sobie. Wspótczesna autorefleksja: jednostka, społeczeństwo, historia, red. P. Kowalski, wstęp J. Tazbir, wyb. S. Zagórski, Łomża 2005, s. 175 .

${ }^{13}$ Ibid.

${ }^{14}$ K. Jaskułowski, Mcnacjonalizm czyli kultura popularna w stużbie narodu, „Kultura Popularna” 2006, nr 3, s. 9.

${ }^{15}$ Zob. ibid., s. 9-17.

16 M. Billig, op. cit.

${ }^{17}$ K. Jaskułowski, op. cit., s. 9. 
Deskrypcja serbskiego i chorwackiego gastronacjonalistycznego menu jest szczególnie wyrazista, a jednocześnie wyjątkowo skomplikowana. Istotne w tym kontekście znaczenie ma typowe dla obu narodów doświadczenie spotkania z innym, zwykle zagrażającym innym ,względem którego będzie można manifestować swoją kulturową odrębność"18, a także trzeba będzie odróżnić się „na jak największej liczbie płaszczyzn"19. Usilne wzajemne odseparowywanie staje się przyczynkiem do manifestowania kultury narodowej, bez względu na to, czy „eksponowane tradycje regionalne są prawdziwe czy tylko wymyślone" ${ }^{20}$. Mechanizmy te, posiadające często absurdalny charakter i komiczną formę, sprowadzają się do operowania nacjonalistycznym stereotypem, jednocześnie niosąc ze sobą poważne niebezpieczeństwa:

(...) w zmienionych okolicznościach dziejowych ktoś nazbyt „serbski” może okazać się nie dość „ludzki”, aby pozwolić mu żyć. Można się śmiać z narodowych stereotypów, odbitych w zwierciadle zwykłego dnia, ale nie sposób zlekceważyć drzemiącą w tym potencjale moc, która potrafi zbudzić upiora nacjonalizmu, jak wielokroć miało to miejsce w historiii ${ }^{21}$.

Spożywane potrawy mogą służyć także, jak sugeruje Grzegorz Piotrowski, „wyznaczaniu granic poszczególnych rejonów etnicznych"22. Przy tej okazji warto wspomnieć mechanizm narcyzmu małych różnic ${ }^{23}$, który podstawy nieprzyjacielskich stosunków upatruje w minimalnych różnicach między narodami podobnymi do siebie pod względem etnicznym, językowym czy kulturowym. Ta cywilizacyjna kontradykcja, leżąca u postaw konfliktów takich narodów jak Tamilowie i Syngalezi czy Hutu i Tutsi, jest wyjątkowo istotna w kontekście konfliktów serbsko-chorwackich. W odróżnieniu bowiem od Serbów i Chorwatów, jak wskazuje Christopher Hitchens ${ }^{24}$, Tamilowie obdarzeni są ,przynajmniej” ciemniejszą karnacją i niższym wzrostem od Syngalezów, podobnie zresztą jak Hutu i Tutsi, którzy już na pierwszy rzut oka różnią się od siebie wzrostem i fryzurą (te spostrzeżenia kolonialnych antropologów bynajmniej nie stanowią przesłanki do konfliktu ${ }^{25}$ ). Dlatego też wszystkie istniejące odmienności będą w omawianym przypadku obsesyjnie podkreślane w celu wzajemnego odróżnienia. Wymownym przykładem jest kwestia podnoszonej do rangi symbolu tożsamościowego religii. Szczególną rolę odgrywa również język, który, jak wskazują lingwiści ${ }^{26}$, w pro-

18 Ibid.

19 Ibid.

20 D. Bell, G. Velentine, Consuming Geographies, London 1997, s. 148 [za:] A. Wieczorkiewicz, Caty świat $w$ zasięgu smaku [w:] Kultura w czasach globalizacji, red. M. Jacyno, M. Kempny, A. Jawłowska, Warszawa 2004, s. 206.

${ }_{21}$ A. Sekuła, Niebezpieczne zwiazki wedtug Edensora, „Kultura Popularna” 2006, nr 3.

${ }^{22}$ G. Piotrowski, Gastronacjonalizm od kuchni, „Kultura Popularna” 2006, nr 2, s. 19.

23 Sformułowanie pochodzi od Freuda, zob. Ch. Hitchens, The Narcissism of the Small Difference, http://www.slate.com/articles/news_and_politics/fighting_words/2010/06/the_narcissism_of_the_ small_difference.html (dostęp: 08.01.2017). W tym momencie przywołać można także ustalenia Juliana Korhnahusera o lęku małych narodów przed niezrozumieniem ich odrębności, zob. idem, Świadomość regionalna i mit odrębności. O stereotypach w literaturze serbskiej i chorwackiej, Kraków 2001.

${ }^{24}$ Ch. Hitchens, op. cit. (dostęp: 08.01.2017).

25 Ibid.

26 Zob. np. S. Kordić, Jezik i nacionalizam, Zagreb 2010. 
cesie konstruowania się nacji został zinstrumentalizowany do nacjonalistycznych celów budowania mitu odrębności ${ }^{27}$.

Nie bez znaczenia dla pojęcia tożsamości pozostaje także wyodrębnianie się korpusu nowych tradycji ${ }^{28}$, czyli proces wypełniania nowymi (nie zawsze historycznie prawomocnymi) znaczeniami pustych miejsc narodowej matrycy kulturowej. Wyrazem „wynajdywania”29 tradycji jest np. „kartografowanie ojczyzny”, czyli tworzenie nowych map mentalnych koncentrujących się zwykle na opozycjach $^{31}$, np. my-Europa vs. oni-Bałkany, my-stary naród vs. oni-naród wymyślony itd. Podobne delimitacje opisuje Edensor jako substrat w procesie tworzenia „,narodowych geografii” ${ }^{2}$, ściśle związany z kształtowaniem się poczucia przynależności.

$\mathrm{Na}$ specyfikę serbsko-chorwackiego exemplum silnie wpływają czynniki natury politycznej, związane z wyznaczeniem nowych granic. Krwawy rozpad Federacji czy inne ,zaszłości” nie przeszły tu bez echa. Wspomnieć można choćby doświadczenie pogranicza, specyficzną świadomość jugosłowiańską wypieraną w trakcie transformacji, będącą ,splotem »socjalistycznej świadomości i narodowej podświadomości «"33, cały szereg wytworzonych w trakcie współistnienia w ramach Jugosławii kompleksów narodowych, ewokujących ,poszukiwania podpórki tożsamościowej” dla ,podreperowania własnego wizerunku”34. Warto wreszcie wymienić powojenne spustoszenie gospodarki i powolną jej odbudowę, czy też kierunek polityczny, wyznaczany przez znajdujące się wówczas u władzy radykalne nacjonalistyczne ugrupowania polityczne, na czele z Franjem Tuđmanem i Slobodanem Miloševiciem.

${ }^{27}$ Należy zaznaczyć, że istnieją także inicjatywy sprzeciwiające się konfliktogennej postawie, czego najbardziej wymownym przykładem jest przyjęta w Sarajewie w kwietniu 2017 roku „Deklaracija o zajedničkom jeziku” [Deklaracja o wspólnym języku]. Dokument, podpisany przez ponad osiem tysięcy osób [dane na maj 2017], w tym wielu lingwistów i innych intelektualistów z Chorwacji, Czarnogóry, Bośni i Hercegowiny oraz Serbii, nie forsując żadnej konkretnej nazwy, uznaje język, którym posługują się mieszkańcy wymienionych krajów, za „wspólny standardowy język policentrycznego typu, którym mówi parę narodów w paru państwach, gdzie występuje on w dystynktywnych wariantach". Zob. http://www.danas.rs/drustvo.55.html?news_id=342456\&t itle=Predstavljena+Deklaracija + o+zajedni\%C4\%8Dkom+jeziku; http://jezicinacionalizmi.com/ deklaracija/ (dostęp: 5.04.2017).

${ }^{28}$ Zob. T. Edensor, op. cit., s. 55-65.

${ }^{29}$ Zob. E. Hobsbawm, op. cit., s. 9-23.

${ }^{30}$ K. Luketić, Balkan: od geografije do fantazije, Zagreb 2013.

${ }^{31}$ Które wyznaczają dwie osie przestrzennego podziału: poziomą, wskazującą geograficzny kierunek (Zachód, Wschód, Europa, Bałkany), oraz pionową, osadzoną na skali wartości (nasze, obce, smaczne, niejadalne, pozytywne, negatywne i in.).

32 T. Edensor, op. cit.

${ }^{33}$ D. Oraić Tolić, Stereotypy kulturowe i nowoczesny naród, przeł. B. Zieliński [w:] Widzieć Chorwację, Panorama literatury i kultury chorwackiej 1990-2005, red. K. Pieniążek-Marković, G. Rem, B. Zieliński, Poznań 2005, s. 17; M. Dyras, Re-inkarnacje narodu. Chorwackie narracje tożsamościowe w latach dziewięćdziesiątych, Kraków 2009, s. 12.

34 Ibid., s. 29. 


\section{Znów wszystko wyszło na opak: deskrypcja współczesnego nacjonalistycznego menu}

Współczesne nacjonalistyczne menu skomponował premier Serbii Aleksandar Vučić, a ,podano” je na wspomnianej konferencji prasowej po nieudanej próbie ponownego uruchomienia linii kolejowej łączącej stolicę Serbii z Kosowem po ponad 18-letnim przestoju. „Po osobistej interwencji” ${ }^{35}$ premier, kierując się ,,ratowaniem ludzkiego życia i aby uniknąć konfliktu o dużej skali”" ${ }^{36}$, podjął decyzję o zawróceniu pociągu, który jego zdaniem ,nie jest żadną groźbą, podobnie zresztą jak groźbą nie są czekoladka czy đuveč" 37 . Jak wskazał w przemówieniu, które przerwało wieczorną transmisję sobotniego programu publicznej telewizji ${ }^{38}$ :

Pociąg ruszył w drogę, pociąg - nie czołg, i wtedy zaczęły dziać się niewiarygodne rzeczy. Dziś wieczorem dowiedzieliśmy się, że Albańczycy, tj. ich siły specjalne, podjęły próbę zaminowania części torów. Jednak nawet tego nie potrafili wykonać w odpowiedni sposób ${ }^{39}$.

Należy jednak zauważyć, że ,pociąg-nie-czołg” nie był pociągiem zwyczajnym. Przed inauguracyjną podróżą ,hitem internetu” stały się zdjęcia składu oklejonego prawosławnymi ikonami oraz serbskimi symbolami narodowymi, na którym widniał przetłumaczony na 21 języków, w tym oczywiście także na język albański, napis „Kosowo jest serbskie”. Mimo rzekomego przesłania pokoju, który ,jest całkowicie w interesie każdego" ${ }^{40}$, nawet przyzwyczajonemu już do tego typu wypowiedzi narodowi, oglądającemu właśnie przefiltrowaną wersję własnej historii w filmie Za króla i ojczyznę ${ }^{41}$, ciężko było uwierzyć w pokojowe intencje ,propagandy na szynach"42.

35 http://www.kurir.rs/vesti/politika/premijer-o-situaciji-na-kosovu-vucic-specijalci-rosu-hteli-daminiraju-prugu-i-uhapse-masinovodu-clanak-2634599 (dostęp: 15.01.2017).

36 Ibid.

37 http://www.alo.rs/vucic-odlucio-sam-da-zaustavim-voz-u-raskoj/91062 (dostęp: 14.01.2017). Jeśli nie zaznaczono inaczej, wszystkie tłumaczenia pochodzą od autorki tekstu.

${ }^{38}$ Co ciekawe, akurat emitowano film Za kralja i otadžbinu w reżyserii R. Bajicia na podstawie popularnego serialu telewizyjnego Ravna gora. Film z 2015 roku w niezwykle patetyczny i historycznie nieobiektywny sposób, bazując na nacjonalistycznej serbskiej perspektywie, przedstawia historię Dragoljuba „Dražy” Mihajlovicia i jego wojsk w trakcie drugiej wojny światowej. Czetnicy Dražy Mihajlovicia to wojska, które pozostały wierne serbskiemu królowi, walcząc w trakcie wojny nie tylko przeciwko nazistowskim okupantom (zatem i chorwackim Ustaszom), ale i partyzantom Tity (dopuszczając się także masakr na ludności cywilnej), obecnie uważani są za symbol wielkoserbskiej opcji politycznej. Określenie „czetnik”, podobnie jak „ustasza”, funkcjonuje w dyskursie nacjonalistycznym do dziś.

39 http://www.kurir.rs/vesti/politika/premijer-o-situaciji-na-kosovu-vucic-specijalci-rosu-hteli-daminiraju-prugu-i-uhapse-masinovodu-clanak-2634599 (dostęp: 15.01.2017).

40 Ibid.

${ }^{41}$ Oczywiście trudno założyć, że dobór repertuaru filmowego był w jakikolwiek sposób świadomy i celowy, jednak w tym kontekście emisja akurat tego obrazu jest niezwykle wymowna, a zwrócić należy także uwagę na częstą obecność obrazów forsujących nacjonalistyczną wersję historii w serbskiej telewizji publicznej.

42 T. Pančić, Mala čokoladna patologija, Vreme br. 1354, 15 grudnia 2016, zob. http://www. vreme.com/cms/view.php?id=1450856 (dostęp 15.01.2017). 
Pierwszy składnik analizowanego gastronacjonalistycznego „menu” „zaserwowała" prezydent Chorwacji Kolinda Grabar-Kitarović w trakcie wizyty w jednym z przedszkoli w Dubrowniku ${ }^{43}$ z okazji Dnia Obrońców Ojczyzny. Przedszkolacy, znów nie „byle jacy”, bo „dzieci chorwackich obrońców ojczyzny”44, obdarowani zostali przysmakami, wśród których znalazły się czekoladki wyprodukowane w fabryce Pionir w Suboticy. „Czego brakuje Pionirowi, a co dziwnego w Suboticy?” można spytać za Pančiciem:

Nic, oprócz tego, że przez ostatnich prawie sto lat leży ona w Serbii, no cóż, tak się złożyło, co zrobić. Zatem, czekoladki są serbskie, a jak to tak, że Prezydent Chorwacji, patriotka high class, osobiście rozdaje serbskie słodycze i to nikomu innemu, jak potomkom obrońców ojczyzny, którzy ryzykowali swym życiem w obronie przed wielkoserbskim smokiem?45

Popkulturowy kontekst „wojny” obrazuje fakt, że zainteresowanie sprawą wywołał rozzłoszczony ${ }^{46}$ rodzic, który opublikował na swoim facebookowym profilu zdjęcie niefortunnych podarunków ${ }^{47}$. Choć oficjalne przeprosiny prezydent pojawiły się natychmiast ${ }^{48}$, afera „Čokolinda”, nazwana tak od jej imienia i chorwackiej čokolady, stała się tematem numer jeden i wywołała rozmaite reakcje. Serbski i chorwacki „Dziennik” w ramach swoich głównych wydań zajął się szczegółową analizą statystyk wzajemnego importu i eksportu, internet zalała fala obrazków satyrycznych, a dziennikarze portalu Index.hr rozdawali w Zagrzebiu przechodniom osławione „serbskie" czekoladki. W Serbii wnioskowano o bojkot chorwackich produktów, i jak wskazuje Pančić, na każdym kroku jednoznacznie nazywano zaj-

${ }^{43}$ Obrona Dubrownika, który mimo iż wpisany na Listę Światowego Dziedzictwa UNESCO, został częściowo zniszczony przez wojska Jugosłowiańskiej Armii Ludowej, jest jednym $\mathrm{z}$ istotnych symbolicznych wydarzeń w historii Chorwacji. Okupacja Dubrownika w ramach chorwackiego dyskursu wojennego, obok bitwy o Vukovar, operacji Oluja i paru innych, stanowi jedno z najistotniejszych symbolicznych wydarzeń wojennych o szczególnym znaczeniu tożsamościowotwórczym.

${ }^{44}$ Hrvatski branitelji - sformułowanie funkcjonujące w chorwackim dyskursie historycznym i politycznym, oznaczające aktywnych uczestników konfliktu w byłej Jugosławii, którzy zgodnie $\mathrm{z}$ chorwackim dyskursem uczestniczyli w obronie przeciw wielkoserbskiej agresji oraz w konflikcie w Bośni i Hercegowinie. Po wojnie obrońcy zorganizowali stowarzyszenia weteranów. Jako odrębna grupa społeczna w Chorwacji, posiadają oni własny zbiór zapisów prawnych. W ostatnich latach najczęściej pojawiają się w mediach w związku z licznymi protestami przeciwko niewystarczającej opiece ze strony państwa. Zob. http://www.vecernji.hr/hrvatska/pred-saborom-prosvjeduju-djelatniciriz-a-imunoloskog-i-branitelji-iz-savske-1007802 (dostęp: 20.02.2016).

45 T. Pančić, op. cit.

46 Oryg. wyrażenie w facebookowym żargonie brzmi ,feeling angry”.

47 Jak napisał na swoim profilu: „Musiałem to wstawić, żebyście zobaczyli, w jakim państwie żyjemy, jego [dziecka] przedszkole było na spotkaniu z Kolindą [Grabar-Kitarović] i oto co dostał z jej rąk, jej zdjęcie i czekoladę z serbii, czy to nie żałosne, i to w Dzień Obrońców Ojczyzny, brawa" [pisownia oryginalna]. Zob. http://www.tanjug.rs/full-view.aspx?izb=289516 (dostęp: 18.01.2017).

48 „Jestem wyjątkowo rozczarowana, ponieważ osobiście reprezentuję i wspieram kampanię Kupujmy chorwackie produkty. W koszyku z łakociami znalazły się produkty, które nie są chorwackiej produkcji, a które znajdują się na chorwackim rynku. Chorwacka Prezydent musi promować chorwackie produkty, taka sytuacja już więcej się nie powtórzy. Do rodziców, którzy dostali te czekoladki, zostaną skierowane przeprosiny i wysłane chorwackie produkty”. Zob. http://www. telegraf.rs/vesti/2500964-afera-cokolinda-hrvati-objasnili-da-su-srpske-cokoladice-pakovane-u-vukovaru-grabar-kitarovic-se-izvinila-zbog-incidenta (dostęp: 18.01.2017). 
ście ,aktem brutalnego nacjonalizmu" ${ }^{\text {"49 }}$. Okazało się jednak, że to nie koniec nacjonalistycznych ,,przepychanek” o łakocie, gdyż „na deser” pozostał epizod z Vuko$\operatorname{varu}^{50}$, gdzie jak co roku uczniowie szkół podstawowych otrzymali w prezencie od władz Splitu bożonarodzeniowe prezenty. Problem polegał jednak na tym, że zostały one rozdzielone wszędzie, z wyjątkiem serbskiej szkoły podstawowej im. Nikoli Andricia, a precyzyjniej rzecz ujmując, serbskiej zmiany tej szkoły ${ }^{51}$. Serbskie media przyjęły to jako „,nowy przypadek ludobójstwa w ustaszowskiej ${ }^{52}$ Chorwacji”.

„Skandal! Dzieci serbskiej narodowości zostały bez prezentów!!” - wrzeszczał z kiosków „Blic”. „Nie ma paczek dla serbskich dzieci” - donosił „B92”. „Vukovarska szkoła zabroniła, aby serbskie dzieci dostały prezenty!” - wyjaśniał doskonale poinformowany „Telegraf”. „Dno dna!” - odgrażały się „Vesti”"53. Pytano w usprawiedliwionym gniewie: „Czy kiedyś skończy się nagonka na Serbów w Chorwacji?” „Serbia powinna teraz wysłać tym dzieciom największe i najpiękniejsze bożonarodzeniowe podarki!!” - brzmiał typowy, losowo wybrany komentarz z serbskich portali ${ }^{54}$.

Finalnie okazało się, że to serbscy nauczyciele podjęli decyzję o rozdaniu upominków wyłącznie chorwackim dzieciom, celem „uniknięcia nieprzyjemności” ${ }_{55}$, gdyż jak tłumaczy „na chorwacki” Dežulović, „nie chcieli bez konsultacji z rodzicami doprowadzić do sytuacji, w której prawosławne dzieci miałyby przyjąć prezenty na katolickie Boże Narodzenie" ${ }^{56}$. Chorwackie media tylko czekały na nowy przypadek „Barykadowej Rewolucji” ${ }^{57}$ w Chorwacji.

49 T. Pančić, op. cit.

50 Vukovar - miasto położone nad Dunajem, w północno-wschodniej Chorwacji, przy granicy z Serbią. Przed wojną mieszane etnicznie, zamieszkiwane głównie przez ludność serbską i chorwacką. W trakcie wojny stało się miejscem dramatycznych wydarzeń W wyniku oblężenia i bitwy o Vukovar, doszło do zniszczenia miasta i masakry ludności cywilnej, a samo miasto stało się symbolem chorwackiej martyrologii.

51 Serbowie, którzy tworzą mniejszość etniczną w Vukovarze, mają zagwarantowane prawo do używania swojego języka, m.in. przez dostęp do edukacji w języku serbskim. W praktyce jednak taka struktura edukacyjna przyczynia się do izolacji serbskich i chorwackich mieszkańców miasta. W Vukovarze działają osobne przedszkola, a wybór placówki zwykle dyktowany jest kwestiami przynależności narodowej, szkoły z kolei realizują zajęcia w jednym budynku, jednak istnieją osobne chorwackie i serbskie klasy, prowadzone przez innych nauczycieli, co przypieczętowuje politykę edukacyjnej i językowej izolacji. http://balkans.aljazeera.net/vijesti/odvojeni-zivoti-djece-u-vukovaru (dostęp: 8.01.2017).

52 Ustasze to pierwotnie organizacja terrorystyczna działająca przed drugą wojną światową, jednak w serbsko-chorwackim dyskursie określenie ,ustasze” nawiązuje do wydarzeń z okresu drugiej wojny światowej, kiedy to organizacje ustaszowskie stanęły na czele marionetkowego nazistowskiego Niezależnego Państwa Chorwackiego. Współcześnie przymiotnik „ustaszowski” nawiązuje do nazizmu szczególnie w kontekście popularnych rehabilitacji chorwackiego faszyzmu, co stanowi istotny problem chorwackiego społeczeństwa, zob. http:/www.index.hr/vijesti/clanak/uefa-nacrtala-hrvatima-ovo-su-zabranjeni-ustaski-simboli-/900433.aspx (dostęp: 12.01.2017). Ustasze to także ,antyczetnicy”.

53 „Blic”, „B92”, „Telegraf”, „Vesti” - najbardziej popularne serbskie dzienniki i portale informacyjne.

54 B. Dežulović, Smisao Božića, Novosti, kolumne 25 grudnia 2016, http://www.portalnovosti. com/smisao-bozica (dostęp: 26.12.2016).

55 Ibid.

56 Ibid.

57 Chorw. Balvan revolucija - w trakcie trwania sezonu turystycznego w 1990 r. Serbowie z Krajiny (byłego pogranicza wojskowego, terenów zamieszkanych wówczas w dużym odsetku 
„Nie pozwolili dzieciom serbskiej narodowości przyjąć prezentów na Boże Narodzenie!” - wrzeszczał z kiosków „Večernji list”58. „Bezwstydna decyzja!” - odgrażało się „Dnevno. hr” w usprawiedliwionym gniewie: „Smutek! Vukovarskim dzieciom serbskiej narodowości nauczyciele zabronili przyjąć świąteczne prezenty!” „Serbowie się samodyskryminują, nie chcą integracji z chorwackim społeczeństwem”, brzmiał typowy, losowo wybrany komentarz z chorwackich portali ${ }^{59}$.

Trudno wszak oczekiwać jedności w Boże Narodzenie, które daje możliwość do prezentowania odrębności (religijnej) i wyznaczania granicy pomiędzy ,,swoim” a „obcym”. Pokojowa świąteczna atmosfera to, jak widać, wyłącznie utopijna wizja nieosiągalna w sytuacji, w której już sama poprawność graniczy ze ,świątecznym cudem" 60 . Jak twierdzi w kwestii cudów Pančić, jedynym dostępnym „magicznym światem” jest świat nacjonalistów, którego czar polega na tym, że nacjonalistami nigdy nie jesteśmy „my”, a zawsze „oni”:

(...) typowa nacjonalistyczna mantra współczesności brzmi: „To nie my jesteśmy nacjonalistami, lecz oni”! Działa ona paradoksalnie, ale jest główną linią drobnomieszczańskiego nacjonalizmu naszych czasów: poniekąd bowiem zdaje sobie sprawę, że nacjonalizm to coś moralnie i intelektualnie wątpliwego, nie wspomina zatem o nacjonalizmie osobiście i bezpośrednio, a zawija go w celofan defensywy - ona się tylko „broni” przed cudzym nacjonalizmem ${ }^{61}$.

\section{Ostatni element proponowanego menu to đuveč, dla niewtajemniczonych:}

(...) danie złożone z ryżu, cukinii, cebuli, papryki, marchewki i duszonych pomidorów, doprawione solą, oregano, tymiankiem, rozmarynem i liściem laurowym, na myśl o którym wielbiciele mięsa drżą tak samo, jak na myśl o panierowanym bakłażanie - kuchennymi drzwiami dostał się do chorwackich sił zbrojnych. Wieść ta niewarta byłaby odnotowania, wszak warzywa są zdecydowanie tańsze od mięsa, gdyby na konserwie z potrawką, przeznaczoną specjalnie dla chorwackiego wojska, nie widniało przerażające „kraj pochodzenia: Serbia" ${ }^{\prime 2}$.

Goran Borković podsumowuje ironicznie: „to policzek!”63. I chociaż zgodnie z chorwacką hierarchią wrogów to oczywiście serbski produkt wzbudził najwięcej emocji, w dziennikarskim dochodzeniu ustalono, że ,gwaranci chorwackiego

przez Serbów, którzy osiedlili się tu już w XVII i XVIII w.) zabarykadowali m.in. drzewami i kamieniami drogi prowadzące nad Adriatyk, blokując przejazd zmierzających na wakacje wczasowiczów.

${ }^{58}$ „Večernji list”, „Dnevno.hr” - najbardziej popularne chorwackie dzienniki i portale informacyjne.

${ }^{59}$ B. Dežulović, op. cit.

${ }^{60} \mathrm{~W}$ cytowanym felietonie Dežulović nakreślił wizję idealnego, utopijnego chorwackoserbskiego świata, w którym władze Splitu wysłałyby dzieciom z Vukovaru świąteczne prezenty, z tym że chorwackim szkołom na katolickie, a serbskim na prawosławne Boże Narodzenie. Na uroczystości z okazji katolickich świąt w Szkole Podstawowej im. Nikoli Andricia dzieci z serbskiej zmiany wspólnie z rodzicami rozdawałyby prezenty chorwackim przyjaciołom, a ich rówieśnicy z chorwackiej zmiany wraz z rodzicami dwa tygodnie później przygotowaliby podarunki z okazji świąt prawosławnych.

${ }^{61}$ T. Pančić, op. cit.

${ }^{62}$ G. Borković, Ko je Hrvatima skuvao srpski đuveč, Al Jazeera Balkans, 31 grudnia 2016, http:// balkans.aljazeera.net/vijesti/ko-je-hrvatima-skuhao-srpski-duvec (dostęp: 31.12.2016).

63 Ibid. 
partykularyzmu” oprócz „nie daj Boże!” serbskiego đuveču żywieni są również macedońskim ajvarem $^{64}$, fasolą sprowadzaną z Włoch i, co najbarwniejsze, ,węgierskimi" sardynkami ${ }^{65}$.

\section{Przeżyjmy to jeszcze raz, czyli nacjonalistyczne menu lat 90.}

Aby udowodnić długie trwanie identyfikacyjnych kulinarnych potyczek, wskazać należy parę przykładów „nacjonalistycznego menu” rodem z końca XX wieku ${ }^{66}$. W kontekście wspomnianych na początku map mentalnych wymienić można trzy zasadnicze, których granice wyznacza drób (afirmowany przez nacjonalistyczny dyskurs jako główne źródło mięsa w Chorwacji) i wieprzowina (jako symbol serbskości) ${ }^{67}$, wino (symbol chorwackiej przynależności do kultury śródziemnomorskiej) ${ }^{68}$ i rakija (jako oznaka serbskiej ruralnej tożsamości narodowej) ${ }^{69}$ czy też szczególnie ciekawy krąg łakoci (serbskie orientalne słodkości kontra chorwackie torty w stylu wiedeńskim, świadczące o przynależności do Europy Środkowej $)^{70}$. Wymienione centra kulturowych przestrzeni zasadzają się na tworzeniu korpusu nowych środkowoeuropejskich i śródziemnomorskich tradycji ze strony chorwackiej, a także na opozycyjnie występującym po stronie serbskiej wyraźnym akcentowaniu pierwiastka prawosławnego, wschodniego i ludowego ${ }^{71}$. Za inne przykłady uznać można produkty spożywcze stanowiące manifestacje tożsamości narodowej, które pojawiły się w trakcie wojny, takie jak opisywane przez Dubravkę Ugrešić szynka z wtłoczonym w mięso wzorem w kształcie chorwackiego herbu ${ }^{72}$ czy puszka ze świeżym chorwackim powie-

${ }^{64}$ Ajvar-gęsta pasta warzywna ,pieczona” na wielką skalę, także w gospodarstwach domowych w ramach przygotowania spiżarnianych zapasów na zimę. Pakowany do słoików, w wersji pikantnej i łagodnej, dostępny powszechnie w każdym niemal sklepie na terenie krajów ,regionu”, zatem m.in. w Chorwacji, Bośni, Serbii i Macedonii czy Czarnogórze, a jako popularny bałkański produkt eksportowy także poza nimi.

65 G. Borković, op. cit.

66 J. Gwioździk, Bonkulovići hrvatskog nacionalizma: pileće krilce ili svinjski but? Kulinarske potrage stazama hrvatskog identiteta, Književna revija: časopis za književnost i kulturu, God.55 (2015), 4.

${ }^{67}$ A. Tomić, Meso bez pedigrea [w:] idem, Smotra folklora, Zagreb 2001, s. 48; D. Drndić, Canzone di guerra, Zagreb 1998; M. Dyras, op. cit.

68 J. Gwioździk, Serbskie i chorwackie zamiłowania alkoholowe z gastronacjonalizmem $w$ tle, Małe przyjemności: katalog słowiański, red. E. Solak, Kraków 2016.

69 Ibid.

${ }^{70}$ Ciasteczko doskonale ilustruje kwestie „ucieczki Chorwacji z Bałkanów”, zob. K. Luketić, op. cit., s. 195. Ciasteczko pojawia się także w rozprawie Magdaleny Dyras Re-inkarnacje narodu, gdzie wskazane jest jako zgrabna metafora historii i tożsamości chorwackiej, zob. Paprenjak.

71 Środkowoeuropejskie cesarstwo domków z ciastek i baklawa w bałkańskiej karczmie. Bałkańska karczma to metafora bałkańskiego stanu ducha i kultury, autorstwa Miroslava Krležy, zob. J. Gwioździk, Serbskie i chorwackie..., środkowoeuropejskie cesarstwo domków zbudowanych z ciasteczek, metafora Branimira Donata, zob. M. Dyras, op. cit., s. 17-20.

${ }^{72}$ D. Ugrešić, Kultura laži, Zagreb 1996, s. 64; eadem, Muzej bezuvjetne predaje, Zagreb 2002. 
trzem $^{73}$. Z kolei ilustracją językowego nacjonalizmu lat 90. w obrębie kulinariów niech będzie książka kucharska Jugosłowiańskiej Armii Ludowej, a raczej jej peryfraza przedstawiona w filmie Kucharze historii ${ }^{74}$ przez służącego w Vukovarze chorwackiego kucharza, który powody wybuchu konfliktu zarysował następująco:

Wszystko tu napisane jest po serbsku, to nie jest mój język. Mój to chorwacki. Na czym konkretnie polega problem i różnica? Na przykład tu napisane jest restovana džigerica [duszona wątróbka], a nie jak mówimy my, dinstana jetrica. Albo boranija u ulju [fasolka szparagowa w oleju], a my przecież nazywamy ją mahune u ulju. To nie jest napisane naszym językiem. My, Chorwaci, nie mogliśmy pisać tych książek, my zawsze byliśmy drugą ligą. Autorzy tych książek to wyłącznie Serbowie. (...) dlatego tylko czekałem, trzydzieści długich lat swojego życia, aby znów gotować dla [swojego] wojska. Kiedy więc „zawrzało"75, ruszyłem, żeby wyzwolić swoje państwo, swoją Chorwację! ${ }^{16}$

\section{Za wątróbkę duszoną i fasolkę w oleju, czyli nieśmiertelne lata 90.}

W obliczu zaprezentowanego nacjonalistycznego menu nie ulega wątpliwości, że strategie budowania własnej tożsamości oraz wzajemne serbsko-chorwackie stosunki niewiele zmieniły się w trakcie „,25 lat wolności”. Oburzenie związane z pochodzeniem banalnych produktów spożywczych wskazuje, jak płytko pod powierzchnią współczesności kryje się poczucie przynależności narodowej ${ }^{77}$, oraz że billigowskie „codzienne oznaczanie ojczyzny” i podkreślanie obecności mitu odrębności ${ }^{78}$ nie są reliktami przeszłości. Sytuacja ta nie pozwala pozbyć się kompleksów narodowych, a tym samym uzyskać dojrzałości i nabrać dystansu do populizmu. Jak podkreśla Maria Bobrownicka:

(...) im dojrzalszy jest naród, tym większą wykazuje zdolność do autokrytycznego obiektywizmu, do wyzwalania się z konwencji zmitologizowanego myślenia o swej przeszłości, na co przeważnie nie stać narodów szczególnie (słusznie czy niesłusznie) zakompleksionych i przez to skłonnych do ulegania populistycznym sloganom demagogicznych haseł kompensacyjnych czy roszczeniowych i grania nimi jako swymi jedynymi atutami politycznymi ${ }^{79}$.

${ }^{73}$ Zob. D. Ugrešić, Esej koji putuje već pune 23 godine, Peščanik 30.05.2015, http://pescanik. net/esej-koji-putuje-vec-pune-23-godine/ (dostęp: 12.09.2016).

${ }^{74}$ Traktującego o największych konfliktach międzynarodowych XX wieku, opisywanych z perspektywy kucharzy wojskowych. Kucharze historii, reż. P. Kerekes, Austria, Czechy, Finlandia, Słowacja 2009.

${ }^{75}$ „Zagotować, usmażyć, pokroić, posiekać, poćwiartować, wypatroszyć - zaskakujące jak język kuchni przypomina niekiedy określenia z pola walki”, zob. opis filmu Kucharze historii, http://www. filmweb.pl/film/Kucharze+historii-2009-510116/desc (dostęp: 12.05.2014).

${ }^{76}$ Zob. Kucharze historii, op. cit.

77 M. Billig, Codzienne zabiegi oznaczania ojczyzny. Nacjonalizm wkrada się w codzienność, „Kultura Popularna” 2006, nr 3 (17), s. 65-82.

${ }^{78}$ Zob. J. Kornhauser, Świadomość regionalna i mit odrębności, Kraków 2001 [za:] M. Dyras, op. cit., s. 17.

${ }^{79}$ M. Bobrownicka, Patologie tożsamości w postkomunistycznych krajach stowiańskich, Kraków 2006, s. 8 . 
Paralelą nastrojów społecznych są wszak wybrani przez naród gracze postjugosłowiańskiej sceny politycznej, a tu głównym warsztatem aktorskim są nie tylko populistyczne manipulacje, ale przede wszystkim przekonania podobne do poglądów przywódców politycznych lat $90 .{ }^{80}$.

Podstawowym mechanizmem nie pozwalającym wyzwolić się spod wpływu lat 90. jest jednak narcyzm małych różnic. Osią konfliktu stało się niechybnie urastające do rangi symbolu wyznanie religijne (przytoczony spór o czekoladki w Vukovarze) oraz oczywiste, acz wypierane, związki gospodarcze i kulturowe (serbskie czekoladki w Dubrowniku produkowane przez popularną we wszystkich republikach jugosłowiańskich firmę Pionir, świętującą w tym roku 100 lat istnienia). Reliktem lat 90. jest także atmosfera patosu i groteski towarzysząca tworzeniu mitów i obsesyjnej selekcji historii. Konsekwencją tego ,głębokiego patologicznego zaburzenia percepcji rzeczywistości, charakterystycznego dla nacjonalistów, zawsze i wszędzie"81 jest „groteskowe wymieszanie znaków i porządków" ${ }^{\prime 2}$, które powoduje, że nazwanie tych szerokości geograficznych Absurdystanem ${ }^{83}$ wydaje się w pełni uprawomocnione, wszak:

(...) to, żeby czekoladki (czy jakiekolwiek inne rzeczy, lub na przykład rośliny czy zwierzęta) posiadały narodowość, nie istnieje nawet w świecie po drugiej stronie lustra, na którą przeszła Alicja ${ }^{84}$.

Niezbitym dowodem na to, jak głęboko sięga konieczność podkreślania własnej odrębności, jest powracający jak mantra ${ }^{85}$ casus obu języków narodowych.

${ }^{80}$ Kolinda Grabar-Kitarović otwarcie nawiązuje do „demokracji inspirowanej postacią dr. Franja Tuđmana”, podczas gdy działalność Aleksandra Vučicia w trakcie wojny (zasadzająca się głównie na jego wielkoserbskich wystąpieniach) czy np. fakt, iż wywodzi się z partii nacjonalistycznego radykała Vojislava Šešelja, jest oficjalnym elementem jego biografii.

81 T. Pančić, op. cit.

82 M. Dyras, op. cit., s. 34.

83 Absurdystan [Absurdistan] to tytuł wydanej w 2013 roku płyty popularnej i głęboko zaangażowanej w kwestie społeczne grupy muzycznej Dubioza Kolektiv. Pytany przez Aleksandra Stankovicia w popularnym chorwackim programie publicystycznym Nedjeljom $u 2$ o atmosferę panującą w Bośni i Hercegowinie, która zainspirowała muzyków do określenia Bośni tym mianem, jeden z liderów zespołu - Brano Jakubović, korzystając z zaskakującej okołokulinarnej metafory, odpowiedział: „BiH jest dla mnie jak fabryka pasztetu. Stoją w niej klatki, a w każdej z nich kurczak. Każdy z nas to właśnie taki kurczak. A klatki są dokładnie takiej wielkości, jaka jest potrzebna kurczakowi do tego, żeby tył. I dostaje wszystko, czego trzeba mu do takiego życia. A na końcu oczywiście wszystkie te kurczaki, czyli nas, posiekają i razem z głową, którą też posiekają, wrzucają do maszyny. Z maszyny wyjdą trzy pasztety, z trzema etykietami. A to, co jest absurdalne, to fakt, że ta fabryka nigdy nie podzieli się na trzy osobne fabryki". Zob. Nedjeljom u 2, program telewizyjny, 13.10.2014, HRT, dostępny pod adresem internetowym: http://www.hrt.hr/enz/nedjeljom-u-dva/223270 (dostęp: 30.04.2014).

84 T. Pančić, op. cit.

85 Podjęty także przez cytowanych publicystów. Wymownym przykładem jest humorystyczny, niestety nie do końca przetłumaczalny na język polski, komentarz wydarzeń w Dubrowniku Deana Milekicia. Opiera się on na prostym gagu polegającym na przemianie małego Chorwata Ivana, po zjedzeniu czekoladki, w Jovana (serbska wersja imienia Ivan), w którego życiu, oprócz tego, że zamiast chodzić do kina (chorw. kino) z tatą (chorw. tata), wybiera się obecnie do ,bioskopu” w towarzystwie „ćaleta” (bioskop i ćale to serbskie warianty słów kino i tata), nie zmieniło się absolutnie nic. „Mali Ivan bio je veselo dijete koje je jako voljelo plesati i s tatom otići u kino. Nakon što je pojeo srpsku čokoladu, nije se dogodilo apsolutno ništa. Mali Jovan i dalje je veseo, mnogo voli igranku i kad ga 
Kwestia usilnego językowego rozróżnienia, najpewniej z powodu braku jakichkolwiek problemów w zakresie komunikacji obu narodów, stała się (oprócz stanowienia zarzewia konfliktów) także tradycyjnym, ponawianym przy każdej okazji powodem żartów ${ }^{86}$. Wymownym przykładem jest symboliczna wojna o język w ujęciu cytowanego chorwackiego kucharza wojennego. Jego zapewnienia, że żaden prawdziwy Chorwat nie może ,udusić" wątróbki, gdy ma do czynienia $\mathrm{z}$ džigerica, a nie jetrica, spuentowany został w cytowanym filmie chichotem dzielących się również swoimi wojennymi wspomnieniami serbskich kucharek.

\section{Śmiech w krajach, którym wcale nie jest do śmiechu}

„Kultura chichotu” w obliczu ery Facebooka i internetu stanowi pewne novum w zakresie poruszanej kwestii. Sprowadzanie zaistniałych wydarzeń do śmiechu stanowi (oddolną i spontaniczną) odpowiedź na absurd nacjonalistycznych potyczek, będąc równocześnie wyrazem oporu i niezgody. Oczywiście w latach 90. także słychać było głosy satyryków politycznych o wyjątkowym poczuciu humoru $^{87}$.

Jednak wszechobecność internetowego medium gwarantuje masowy charakter zjawiska i silnie integruje internautów ze wszystkich byłych republik jugosłowiańskich, między którymi, ze względu na wzajemną zrozumiałość języka, granice wyznaczone w latach 90. przynajmniej w tej kwestii nie istnieją ${ }^{88}$.

ćale odvede u bioskop", zob. http://news-bar.hr/vijesti/hrvatska/strava-u-dubrovniku-mali-ivan-senakon-pojedene-srpske-chokolade-odaziva-is (dostęp: 12.01.2017).

${ }^{86}$ Klasycznym przykładem satyrycznego ujęcia kwestii różnic językowych jest jeden ze skeczów legendarnego programu Top Lista Nadrealista, nagrywanego pod koniec lat 80. i na początku 90. w Sarajewie przez grupę komików uznawanych za jugosłowiańskiego Monty Pythona, m.in. Neleta Karajlicia, Branka Đuro Đuricia, Zenita Đozicia i Davora Dujmovicia, zatytułowanego „Jezici” [Języki]. Profesor doktor Nermin Padež [Przypadek] prezentuje w nim wyniki swoich badań językoznawczych wykonanych wspólnie z profesorem doktorem Nenadem Zamjenicą [Zaimkiem] i profesorem doktorem Stjepanem Zarezem [Przecinkiem], stanowiące epokowe odkrycie - zdaniem tychże naukowców, w lingwistyce nie istnieje jeden błędnie nazywany dotychczas język serbsko-chorwacki, a sześć różnych języków: srpski, hrvatski, bosanski, hercegovački, crnski i gorski. Aby udowodnić swoje odkrycie, profesor doktor, posiłkując się nieomylnym kapownikiem naukowca, przedstawia przykład (gdyż jak wyjaśnia, w lingwistyce najlepiej pracuje się na przykładach) zdania „Ja czytam” [Ja čitam], które brzmi oczywiście we wszystkich językach dokładnie tak samo. Jego wywód powoduje atak senności dziennikarza, który miał przeprowadzać z nim wywiad, oraz poprzedza krótki materiał telewizyjny potwierdzający ,„łłuszność” jego tez. Zob. https://www.youtube.com/ watch?v=DztrX5dXmxU (dostęp: 20.01.2017).

${ }^{87} \mathrm{~Np}$. generacja splitskiego tygodnika „Feral Tribune”, zajmującego się satyrą polityczną. Ważną odnotowania kwestią jest ciągła obecność „Feralovców” (publicystów tygodnika), takich jak cytowany tu Boris Dežulović, Predrag Lucić czy Viktor Ivanović, we współczesnych mediach opiniotwórczych.

${ }^{88}$ Doskonale w "kulturę chichotu” wpisuje się wyjątkowo popularna facebookowa strona „Ćaća se vrača”, zabawnie komentująca analizowane wydarzenia, zob. https://www.facebook. com $/ \%$ C4\%86A\%C4\%86A-SE-VRA\%C4\%8CA-1542978455958131. Ćaća se vrača (pisownia oryginalna), pol. ,powrót taty”, ,wraca tata”, to posiadająca obecnie (dane na 1 stycznia 2017 roku) ponad 156000 polubień, założona przez grupę anonimowych mieszkańców Splitu strona na Facebooku. Głównym obiektem ich aktywności są bieżące wydarzenia polityczne Chorwacji i regionu, a bezpośrednią inspiracją jest Ivo Sanader - były premier Chorwacji, oskarżony o malwersacje finansowe na 
Główny problem tkwi jednak w drugiej, bardziej mrocznej stronie komicznych w swej wymowie wydarzeń, mianowicie w realnych problemach natury ekonomicznej czy obyczajowej, które zepchnięte na boczny plan, wciąż pozostają nierozwiązane. Sytuacja ta uniemożliwia rozwój gospodarczy, a tym samym hamuje dojrzewanie narodu i rozwijanie społeczeństwa obywatelskiego, które tym bardziej staje się podatne na populistyczne zabiegi nacjonalistów. Chodzi np. o wskazaną przez Ilicia groźbę powodzi, która podczas gdy premier komponował nacjonalistyczne menu, z powodu wówczas wciąż nieusuniętego na Dunaju lodu była całkowicie realna, a konsekwencje mogły być dramatyczne w skutkach, tak samo jak w 2014 roku $^{89}$. Z kolei przy okazji czekoladkowego skandalu w Dubrowniku uwagę zwraca fakt, iż oprócz słodyczy nieszczęsnego pochodzenia dzieci otrzymały także fotografie prezydent Grabar-Kitarović opatrzone jej własnoręcznym podpisem. Praktyka ta kojarzy się z kultem jednostki rodem z Korei Północnej, a sama prezydent, idąc w ślady Kim Dzong Ila, jak ironicznie zauważa Milekić, liczy widocznie na głosy obdarowanych przedszkolaków podczas wyborów prezydenckich w 2032 roku $^{90}$. Dežulović, komentując z kolei casus słodyczy rozdawanych z okazji Bożego Narodzenia w Vukovarze, zwraca uwagę na problem wzrostu znaczenia Kościoła katolickiego w życiu politycznym Chorwacji ${ }^{91}$. Publicysta wskazuje, że w normalnym świecie Boże Narodzenie byłoby wyłącznie rodzinnym obyczajem, nie zaś znakiem tożsamości, przez który w obliczu „nacjonalistycznej paranoi” gdzieś zapodział się sens świąt. Kwestia importowanego z Serbii đuveču uświadamia z kolei zapaść gospodarczą Chorwacji, która zmuszona jest sprowadzać produkty tak podstawowego użytku jak ajvar (z Macedonii), czy biorąc pod uwagę narodowe dobro, jakim jest Adriatyk, sardynki, i to z Węgier (!). Tym bardziej że, jak wskazuje Borković, nie chodzi bynajmniej o czasowe braki, ale o głęboką patologię gospodarczą, z powodu której młode pokolenie opuszcza Chorwację, nazywaną przez dziennikarza Strefą Mroku (Twilight Zone ${ }^{92}$ ). Przydo-

wielką skalę. Złapany na granicy podczas próby ucieczki, osadzony w więzieniu, były wróg państwowy numer jeden dzięki cyklowi fotomontaży i głębokiej ironii stał się „ostoją moralności i praworządności”, a na wyjście Ćaćy z więzienia w Zagrzebiu oczekiwał przed budynkiem thum fanów, tzw. ćaćine dice (pol. dzieci tatusia). Strona w ironiczny sposób wyśmiewa polityczne patologie, kolejne afery finansowe i absurdy życia politycznego i społecznego całego regionu. Zob. https://www.facebook. com/\%C4\%86A\%C4\%86A-SE-VRA\%C4\%8CA-1542978455958131/; http://dnevnik.hr/vijesti/hrvatska/caca-se-vraca-viralni-hit-i-pravi-fenomen---428610.html (dostęp: 12.05.2016).

${ }^{89}$ Do walki z lodem wezwane zostały węgierskie lodołamacze, których pochodzenie nie wzbudziło kontrowersji. Ciekawić może wizja, co stałoby się, gdyby jedynym państwem w regionie dysponującym tego typu wyspecjalizowanym sprzętem była Albania.

${ }_{90}$ Zob. http://news-bar.hr/vijesti/hrvatska/strava-u-dubrovniku-mali-ivan-se-nakon-pojedene-srpske-chokolade-odaziva-is (dostęp: 12.01.2017).

${ }_{91}$ Jak pisze Dežulović, zakładając istnienie utopijnego i idealnego, tj. normalnego serbsko-chorwackiego świata, pierwsze pytanie, które zadalibyśmy sobie, brzmiałoby „co w ogóle święta robią w szkole?". Zob. Boris Dežulović, op. cit. Innym przykładem tego zjawiska może być próba połączenia Wydziału Filozoficznego w Zagrzebiu z Wydziałem Katolicko-Teologicznym, która wywołała ostre protesty chorwackich studentów wiosną 2016 roku. Zob. http://www.tportal.hr/vijesti/ znanost/420648/Spajanje-FFZG-a-i-KBF-a-Sto-se-to-zapravo-dogada.html, http://www.portalnovosti. com/vjeronauk-u-autokole (dostęp: 12.12.2016).

${ }_{92}$ Twilight Zone - popularny amerykański serial telewizyjny z 1957 roku, połączenie fantastyki, horroru i science fiction. 
mek ten wydaje się jak najbardziej uzasadniony, biorąc pod uwagę przytoczony przez dziennikarza fakt, że linia produkcyjna przetworów rybnych z adriatyckiej wyspy Vis sprzedana została fabryce mieszczącej się w Niszu, położonym na południu Serbii, która podobnie jak Węgry nie posiada dostępu do morza. Nie trzeba oczywiście dodawać, że ani na Visie, ani też w Niszu nie przetwarza się ryb z Adriatyku, a te kupione w Maroku, Tunezji i Algierii.

\section{Pociag do nacjonalizmu}

Okazuje się, że jesteśmy narodem, który żyje w kuchni. Co jest dobre, bo to właśnie jest nasze prawdziwe życie. To w kuchni wisi zegar i kalendarz, to tutaj w kredensie, w starym pudełku na buty schowane są wszystkie rachunki razem z rezerwowymi uszczelkami do kranu i kluczem francuskim do odkręcania butli z gazem. A drzwi lodówki są jak otwarta gazeta, oficjalne rodzinne ogłoszenia ${ }^{93}$.

Kuchnia to miejsce o wyjątkowym znaczeniu dla całej rodziny. Jak pisze Ante Tomić, to tam odliczany jest czas, tam znajdują się półki i półeczki, które skrywają rodzinne tajemnice i zapisane w przepisach historie kuchenne. Jest to miejsce intymne, sfera porządku prywatnego, do którego obcy nie mają wstępu ${ }^{94}$. Kuchnia to także ważne miejsce w innym ,rodzinnym” kontekście, narodowym. O tym, jakie znaczenie mają narodowe historie kuchenne, a jakie tajemnice skrywają polityczne półki i półeczki dla chorwackiej i serbskiej tożsamości narodowej, można było przekonać się przede wszystkim w latach 90. ubiegłego wieku, kiedy to po rozpadzie Jugosławii i powstaniu państw narodowych czas zaczęto odmierzać od nowa, a święta państwowe zmieniły swoje daty i w wielu przypadkach zaczęły pokrywać się ze świętami religijnymi. Jednak jak się okazuje, rozpoczęta wówczas transformacja ustrojowa i kulturowa, która zmusiła do reinterpretacji własnej tożsamości (również kulinarnej ${ }^{95}$ ) oraz do poszukiwania odpowiedzi na pytania o sens i charakter przemian, do których doszło, nigdy ostatecznie się nie skończyła. Szaleństwo reinterpretacji narodowego kanonu ${ }^{96}$ nie zostało jeszcze zapomniane, a wręcz przeciwnie, ogarnęło Serbię i Chorwację ponownie.

Co łączy pociąg, czekoladki i đuveč? To chroniczna choroba powodująca patologię postjugosłowiańskiej tożsamości, którą obrazowo nazwać można „pociągiem do nacjonalizmu". To ona nie pozwala zapomnieć o koszmarach lat 90. i skupić się na poprawie zarówno wzajemnych stosunków politycznych, jak i stanu gospodarki. Tytułowy pociąg do nacjonalizmu, wbrew upływowi czasu, konsekwentnie zmierza wstecz.

93 A. Tomić, Domaća kuhinja [w:] idem, Smotra folklora, Zagreb 2001, s. 38-39.

${ }^{94}$ Zob. M. de Certeau, op. cit., s. 154-156.

${ }_{95}$ J. Gwioździk, Bonkulovići..., op. cit.

${ }^{96}$ Zob. W poszukiwaniu nowego kanonu. Reinterpretacje tradycji kulturalnej w krajach postjugosłowiańskich po 1995 roku, red. M. Dąbrowska-Partyka, Kraków 2005. Problem kulturowych i tożsamościowych przewartościowań w i po okresie transformacji lat 90 . jest jednym z najistotniejszych i najczęściej podejmowanych zagadnień badawczych ostatnich lat w zakresie nauk slawistycznych. 


\section{Bibliografia}

Bell D., Velentine G., Consuming Geographies, London 1997, s. 148, za: A. Wieczorkiewicz, Cały świat w zasięgu smaku [w:] Kultura w czasach globalizacji, red. M. Jacyno, M. Kempny, A. Jawłowska, Warszawa 2004, s. 206.

Billig M., Banalni nacjonalizam, przeł. V. Kostić, Biblioteka XX wieku, Beograd 2005.

Billig M., Codzienne zabiegi oznaczania ojczyzny. Nacjonalizm wkrada się w codzienność, „Kultura Popularna” 2006, nr 3 (17), s. 65-82.

Bobrownicka M., Patologie tożsamości w postkomunistycznych krajach stowiańskich, Kraków 2006.

Borković G., Ko je Hrvatima skuvao srpski đuveč, Al Jazeera Balkans, 31 grudnia 2016, http://balkans.aljazeera.net/vijesti/ko-je-hrvatima-skuhao-srpski-duvec (dostęp: 31.12.2016).

Bourdieu P., Dystynkcja. Społeczna krytyka władzy sądzenia, przeł. P. Biłos, Warszawa 2005.

Burszta W.J., Kuligowski W., Kotwice pewności. Wojny kulturowe z popnacjonalizmem $w$ tle, Warszawa 2013.

Certeau M. de, Wynaleźć codzienność. Sztuki działania, przeł. K. Thiel-Jańczuk, Warszawa 2004.

Drndić D., Canzone di guerra, Zagreb 1998.

Dyras M., Re-inkarnacje narodu. Chorwackie narracje tożsamościowe $w$ latach dziewięćdziesiątych XX wieku, Kraków 2009.

Edensor T., Tożsamość narodowa, kultura popularna i życie codzienne, przeł. A. Sadza, Warszawa 2004.

Fernàndez-Armesto F., Wokół tysiąca stołów czyli o historii jedzenia, przeł. J. Jackowicz, Warszawa 2003.

Gwioździk J., Bonkulovići hrvatskog nacionalizma: pileće krilce ili svinjski but? Kulinarske potrage stazama hrvatskog identiteta, Književna revija: časopis za književnost i kulturu, God.55 (2015), 4.

Gwioździk J., Serbskie i chorwackie zamiłowania alkoholowe z gastronacjonalizmem w tle, Małe przyjemności: katalog słowiański, red. E. Solak, Kraków 2016.

Hitchens Ch., The Narcissism of the Small Difference, http://www.slate.com/articles/ news_and_politics/fighting_words/2010/06/the_narcissism_of_the_small_difference.html (dostęp: 08.01.2017).

Hobsbawm E., Tradycja wynaleziona, przeł. M. Godyń i F. Godyń, Kraków 2008.

Ilić D., Čokoladice, đuveč i voz, Peščanik, 16.01.2017, http://pescanik.net/cokoladice-duvec-voz/ (dostęp: 16.01.2017).

Jaskułowski K., Mcnacjonalizm czyli kultura popularna $w$ stużbie narodu, „Kultura Popularna" 2006, nr 3, s. 9.

Jezernik B., Naga wyspa. Gułag Tity, przeł. J. Pomorska i J. Sławińska, Wołowiec 2013.

Kiš D., Esej o nacionalizmu [w:] Čas anatomije, Beograd 1978, https://www.scribd. com/doc/81941520/Danilo-Ki\%C5\%A1-Esej-o-nacionalizmu (dostęp: 1.02.2017).

Kordić S., Jezik i nacionalizam, Zagreb 2010.

Kornhauser J., Świadomość regionalna i mit odrębności. O stereotypach w literaturze serbskiej i chorwackiej, Kraków 2001. 
Luketić K., Balkan: od geografije do fantazije, Zagreb 2013.

Łeńska-Bąk K., Kulinaria i dyskurs tożsamości [w:] Polacy o sobie. Współczesna autorefleksja: jednostka, spoleczeństwo, historia, red. P. Kowalski, wstęp: J. Tazbir, wyb. S. Zagórski, Łomża 2005, s. 175.

Oraić Tolić D., Stereotypy kulturowe $i$ nowoczesny naród, przeł. B. Zieliński [w:] Widzieć Chorwacje, Panorama literatury i kultury chorwackiej 1990-2005, red. K. Pieniążek-Marković, G. Rem, B. Zieliński, Poznań 2005, s. 17.

Pančić T., Mala čokoladna patologija, Vreme br. 1354, 15 grudzień 2016, zob. http:// www.vreme.com/cms/view.php?id=1450856 (dostęp 15.01.2017).

Piotrowski G., Gastronacjonalizm od kuchni, „Kultura Popularna” 2006, nr 2, s. 19.

Sekuła A., Niebezpieczne zwiazki wedtug Edensora, „Kultura Popularna” 2006, nr 3.

Tomić A., Smotra folklora, Zagreb 2001.

Ugrešić D., Esej koji putuje već pune 23 godine, Peščanik, 30.05.2015, http://pescanik.net/esej-koji-putuje-vec-pune-23-godine/ (dostęp: 12.09.2016).

Ugrešić D., Kultura laži, Zagreb 1996.

Ugrešić D., Muzej bezuvjetne predaje, Zagreb 2002.

W poszukiwaniu nowego kanonu. Reinterpretacje tradycji kulturalnej w krajach postjugosłowiańskich po 1995 roku, red. M. Dąbrowska-Partyka, Kraków 2005. 